\title{
Standard Dose Prophylaxis Application and Venous Thromboembolism Findings in Patients Who Had Bariatric Surgery
}

\author{
Bariyatrik Cerrahi Yapılan Hastalarda Standart Doz \\ Profilaksi Uygulaması ve Venöz Tromboemboli Sonuçları
}

\author{
Mehmet Aykut Yildirim ${ }^{1}$, Mehmet Isik ${ }^{2}$
}

${ }^{1}$ Necmettin Erbakan University, Meram Faculty of Medicine, Department of General Surgery, Konya, Turkey

${ }^{2}$ Necmettin Erbakan University, Meram Faculty of Medicine, Department of Cardiovascular Surgery, Konya, Turkey

Address correspondence to: Mehmet Isik, Necmettin Erbakan University, Meram Faculty of Medicine, Department of Cardiovascular Surgery, Konya, Turkey

e-mail:drmisik@hotmail.com

Geliş Tarihi/Received: 24 May 2021 Kabul Tarihi/Accepted: 9 August 2021

\begin{abstract}
Öz
Amaç: Obezite cerrahisindeki en önemli morbidite ve mortalite nedenlerinden biri, derin ven trombozu (DVT) ve pulmoner emboliyi (PE) kapsayan venöz tromboembolizm (VTE) olaylarıdır. Bu çalışmada, bariyatrik cerrahi yapılan ve standart doz profilaksisi uygulanan hastalarda VTE sonuçlarının değerlendirilmesi amaçlanmıştır.

Hastalar ve Yöntem: 2015-2019 yılları arasında morbid obezite nedeni ile ameliyat edilen hastalar retrospektif olarak incelendi. Çalışmaya, laparoskopik sleeve gastrektomi yapılan ve standart doz Enoksaparin profilaksisi uygulanan olgular dahil edildi. Hastaların demografik verileri, preoperatif hazırlık ve postoperatif antiembolik tedavi koşulları kaydedildi.

Bulgular: Laparoskopik sleeve gastrektomi yapılan 87 hasta çalışmaya alındı. Hastaların 66 'sı $(\% 75,8)$ kadın 21 'i $(\% 24,1)$ erkekti. Ortalama yaş 38,7 (18-55) idi. Ortalama hastanede kalış süresi 6,6 (3-69) gündü. Dört hastada $(\% 4,5)$ postoperatif komplikasyon gelişti. İki hastada PE, birer olguda sızıntıya bağlı mediastinit ve kesi fıtığı meydana geldi.

Sonuç: Mevcut profilaksi yöntemlerine rağmen, VTE, obezite cerrahisi geçiren hastalarda önemli bir morbidite ve mortalite nedeni olmaya devam etmektedir. Yüksek doz düşük molekül ağırlıklı heparin (DMAH) kullanımı kanamaya neden olabilirken, düşük doz DMAH kullanımı ise VTE olasılığını artırmaktadır. Bu durum, DMAH'ların bir sınırlaması olarak karşımıza çıkmaktadır. Erken dönemde artırılmış doz ve taburculuk sonrası standart doz uygulaması için yeni çalışmalara intiyaç bulunmaktadır.
\end{abstract}

Anahtar Kelimeler: Bariyatrik cerrahi, obesite, düşük molekül ağırlıklı heparin, profilaksi, venöz tromboemboli profilaksisi.

\begin{abstract}
Aim: Venous thromboembolism (VTE) events covering deep vein thrombosis (DVT) and pulmonary embolism (PE) constitute the most important morbidity-mortality cause in obesity surgery. The objective of this study was to assessment of thromboembolism results in patients who underwent bariatric surgery with standard dose prophylaxis.

Patients and Methods: The patients who were operated for morbid obesity in our clinic between 2015 and 2019 were retrospectively examined. Cases that had laparoscopic sleeve gastrectomy and were applied standard dose Enoxaparin prophylaxis were included in the study. Demographic data, preoperative preparation and postoperative antiembolic treatment conditions of the patients were registered.

Results: Eighty-seven patients who had laparoscopic sleeve gastrectomy were included in the study. 66 $(\% 75,8)$ of the patients were female and $21(\% 24,1)$ were male. The mean age was $38.7(18-55)$. Mean hospitalization duration was $6.6(3-69)$ days. Four patients $(\% 4,5)$ had postoperative complication. PE developed in two patients while leak-related mediastinitis and incisional hernia $(\% 1,1)$ developed in one case each.

Conclusion: Despite available prophylaxis methods, VTE constitutes an important morbidity and mortality cause in patients who had bariatric surgery. While high-dose low-molecular weight heparin (LMWH) use may cause bleeding, the possibility of VTE increases with using low-dose LMWH. This situation appears as a limitation of LMWHs. New studies are needed for increased dose at early period and standard dose application after discharge.
\end{abstract}

Key words: Bariatric surgery, obesity, low molecular weight heparin, prophylaxis, venous thromboembolism prophylaxis. 


\section{INTRODUCTION}

Obesity is defined as body mass index (BMI) of $30 \mathrm{~kg} / \mathrm{m} 2$ or higher. It is an important health problem of our age due to its prevalence and the problems it causes. Nearly $1 / 4$ of the adults living in developed or developing countries were reported to be overweight while $1 / 3$ was reported to be obese (1). Ministry of Health Nutrition Research and TURDEP-II (Turkey Diabetes, Hypertension, Obesity and Endocrinological Diseases Prevalence Study-II) study reported the obesity prevalence as $30.3 \%$, mild adiposity prevalence as $34.6 \%$ and morbid obesity prevalence as $2.9 \%$ in adults in our country (2).

Bariatric surgery is an alternative treatment option in patients who cannot succeed through diet, exercise, lifestyle change and pharmacotherapy in obesity treatment. Surgical procedures available today have been shown to produce significant and permanent weight loss (3). Preference prevalence increased as death rates due to all causes decreased $30-40 \%$ in long-term follow-ups following bariatric surgery $(4,5)$. Venous thromboembolism (VTE) events covering deep vein thrombosis (DVT) and pulmonary embolism (PE) constitute the most important morbidity-mortality cause in obesity surgery. Postoperative VTE incidence changes between $0.2 \%$ and $5 \%$ (6-8). PE findings were reported to be clinically suspected in only $20 \%$ of the patients who died after bariatric surgery but PE was present in $80 \%$ of the patients in autopsy (9). The prevalence of VTE complications and the severity of their results give prominence to the importance of preoperative and/or postoperative prophylaxis.

Despite the consensus on bariatric surgery VTE prophylaxis, no consensus has been reached on optimal thromboprophylaxis regimen. The discussion especially on heparin dose strategies adjusted according to patient and surgical characteristics and anticoagulant prophylaxis after discharge from hospital continues. The objective of this study was to assessment of thromboembolism results in patients who underwent bariatric surgery with standard dose prophylaxis.

\section{PATIENTS AND METHODS}

The patients who were operated for morbid obesity in our clinic between 2015 and 2019 were retrospectively examined. Surgical treatment was applied to patients with $\mathrm{BMI}>40 \mathrm{~kg} / \mathrm{m}^{2}$ and $\mathrm{BMI}>35$ $\mathrm{kg} / \mathrm{m} 2$ and at least one comorbid condition (DM, HT, sleep apnea syndrome, dyslipidemia, etc.). Cases that had laparoscopic sleeve gastrectomy and were applied standard dose Enoxaparin prophylaxis were included in the study. Patients who were operated through different surgical methods and those who did not have Enoxaparin prophylaxis were excluded from the study. Attention was paid especially to the lack of cardiac, pulmonary and thromboembolism risk factors in patient selection for bariatric surgery. Surgical treatment was not performed in the presence of any of these risk factors. Case data (age, BMI, complication formation, comorbid disease and habits) were acquired from file records and hospital software system (Table 1). Study approval (2021 / 3215) was obtained from the Local Ethics Committee and written informed patient consent was obtained from each patient.

Respiration exercise was started for the patients preoperatively (3-7 days before). Mechanic prophylaxis (antiembolism stockings) was started to be used on all patients when they were taken to the operation. Mechanic prophylaxis was continued until discharge from the hospital. Starting the first dose in postoperative 12th hour, subcutaneous Enoxaparin $(6000 \mathrm{lU} / 0.6 \mathrm{ml})$ was given with two standard doses (every 12 hours) unconsidering patient weight. Prophylaxis was continued with the same dose and application method after discharge from hospital until postoperative 14th day. Early mobilization (in 4-6th hour in average) was provided for the patients. Regimen 1 was started on postoperative 2 nd day. Oral intake was increased in the following days. Patients

Table 1. Demographic data and complications.

\begin{tabular}{|c|c|c|}
\hline Parameters & $\mathbf{N}$, Mean \pm SD & $\%$ \\
\hline$\overline{\text { Age }}$ & $38.7 \pm 10.4$ & \\
\hline Sex & $\begin{array}{l}F: 66 \\
M \cdot 21\end{array}$ & $\begin{array}{l}75,8 \\
24\end{array}$ \\
\hline DM & 5 & 5,7 \\
\hline $\mathrm{HT}$ & 12 & 13,7 \\
\hline $\mathrm{HT}+\mathrm{DM}$ & 1 & 1,1 \\
\hline Hyperlipidemia & 1 & 1,1 \\
\hline Thalassemia & 1 & 1,1 \\
\hline Smoking & 17 & 19,5 \\
\hline $\mathrm{BMI}$ & $45.7 \pm 6.6$ & \\
\hline Operation time (min) & $153 \pm 41.3$ & \\
\hline \multicolumn{3}{|l|}{ Complications } \\
\hline $\mathrm{PE}$ & 2 & 2,2 \\
\hline Mediastinitis & 1 & 1,1 \\
\hline Incisional hernia & 1 & 1,1 \\
\hline Mortality & 2 & 2,2 \\
\hline
\end{tabular}


who had adequate oral intake and no complications were discharged in two to five days. They were checked on postoperative 10th, 30th and 90th days. VTE conditions developed during the first three months were registered. Patients with dyspnea, lower extremity pain, increased diameter and Homans sign were examined for VTE. Consultation was made with Cardiovascular Surgery and Pulmonary Diseases clinics for the patients considered to have VTE during the follow-ups and their diagnosis and treatment were determined. Doppler USG was applied for DVT and pulmonary CT angiography for PE. Descriptive analysis was conducted for all data.

\section{RESULTS}

Eighty-seven patients who had laparoscopic sleeve gastrectomy were included in the study. $66(\% 75,8)$ of the patients were female and $21(\% 24,1)$ were male. The mean age was 38.7 (18-55). Mean hospitalization duration was 6.6 (3-69) days. The number of patients with ASA score I was $67(77,1 \%)$, and the number of patients with II was $20(\% 22,9)$. Other demographical data are available in Table 1 . Four patients $(\% 4,5)$ had postoperative complications. PE developed in two patients $(\% 2,2)$ while leak-related mediastinitis $(\% 1,1)$ and incisional hernia $(\% 1,1)$ developed in one case each. One of the patients with PE was diagnosed on postoperative day three while the other was diagnosed on postoperative day nine. One of the patients was male (age:19, BMI: 48.9) and the other was female (age:35, BMI: 40.2). Both patients did not have any comorbid diseases or smoking habit. Lower extremity venous DUS was normal for the patients who had PE.

The patient who developed leakage after LSG was revised on the 6th postoperative day. Anastomotic leakage was detected in the gastrectomy line. We observed that the leakage material passed into the mediastinum and caused mediastinitis. Drainage was applied to the fluid accumulated in the mediastinum and dual antibiotics were started. However, the patient developed sepsis. Therefore, long-term hospitalization was required. The patient who developed an incisional hernia was repaired in the 3rd postoperative month. All patients were applied laparoscopic sleeve gastrectomy. Average operation duration was detected as $153 \pm 41.3 \mathrm{~min}$ (Table 1). None of the patients was taken in revision due to bleeding. Two patients (\% 2,2) died. The patient who had mediastinitis died on postoperative day 30 and the one who had PE died on postoperative day 14 .

\section{DISCUSSION}

Stasis, coagulability increase and endothelial damage known as Virchow's triad in VTE pathophysiology was defined nearly 150 years ago (Figure 1). Evidence for obesity forming VTE tendency by contributing to stasis hypercoagulation are present. Abdominal adipose tissue and chronic intraabdominal pressure increase restrict venous return and cause stasis. Obesity was claimed to increase the coagulation cascade activity through leptin and cause thrombosis through decreasing fibrinolysis (10). Nonesterified fatty acids released from visceral adipose tissue contribute to proinflammatory conditions. Inflammation was reported to increase oxidative stress and endothelial dysfunction and high lipid and blood glucose contributed to the prothrombic condition in addition (10). It was found that the relationship between venous thrombosis and obesity became stronger with increasing BMI and risk increase was at least two times higher in individuals with normal weight $(10,11)$. Each stasis, endothelial damage and coagulopathy conditions are effective separately or together in VTE formation in obesity surgery and major surgery interventions (12-14).

Some risk factors were determined for VTE in bariatric surgery. These risk factors were separated into two groups as patient and surgical procedure caused factors. Male gender, increasing age, BMI, smoking and VTE story are among patient-sourced ones (14-17). Each 10 unit increase in BMI causes an

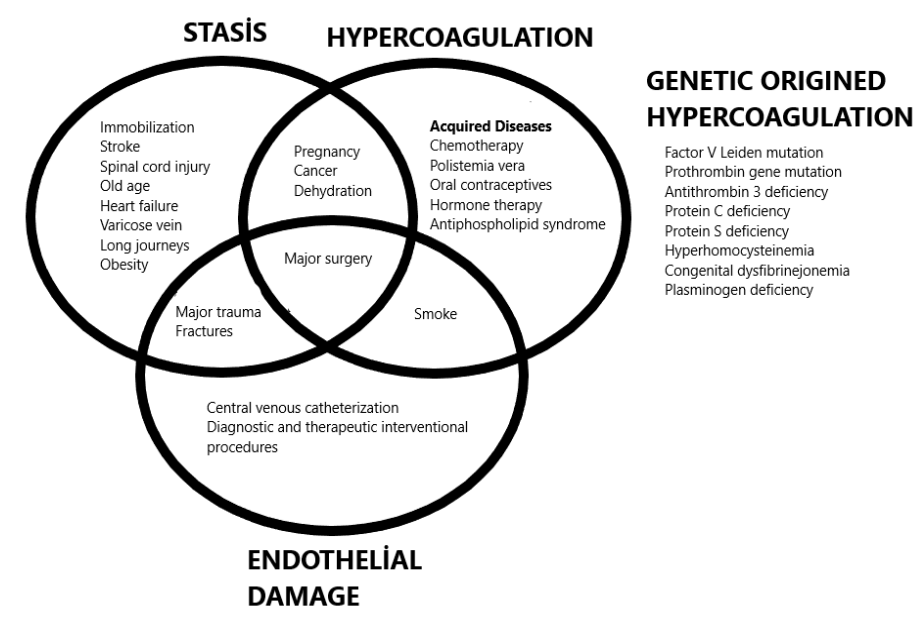

Figure 1. Venous thromboembolism etiology and risk factors. 
increase of $37 \%$ in postop. VTE risk (15). VTE story is reported to increase postoperative VTE risk four times (15).

Surgical procedure caused VTE risk factors are operation duration, surgery type, postoperative revision requirement and open or laparoscopic character of the procedure. It was detected that VTE risk increases when the operation lasts for more than three hours, the risk is higher in open surgery compared to laparoscopic procedures $(15,16,19)$ and that there was a relationship between postoperative revision operations and increased VTE $(18,20)$. Different VTE rates were reported for each procedure based on the comparison of surgical procedures $(15,16)$. Laparoscopic character of the cases and mean operation duration under three hours provided an advantage in terms of PE in our study. Due to the limited number of complications based on our data analysis, a statistical result to interpret patient or surgery caused risk factors could not be acquired. Elastic stockings, multistage compression stockings and intermittent compression devices are used perioperatively and/or postoperatively for mechanic prophylaxis. Use of compression stockings for VTE prophylaxis in general surgery and other surgical cases was reported to provide $60-65 \%$ decrease in postoperative DVT risk $(21,22)$. In a study performing bariatric surgeryliterature search, potential advantages of compression methods were detected and their use in bariatric surgery was strongly recommended (23). Although our study included a PE case, DVT was not observed. The number of cases with the complication was limited to make any evaluation but lack of DVT although PE was observed, makes us consider that lower extremity stasis could be prevented through mechanic prophylaxis.

Unfractionated heparin $(\mathrm{UH})$ or low molecular weight heparin (LMWH) is used for pharmacological prophylaxis today. LMWHs have some pharmacological advantages compared to UH (24). They bond less to plasma proteins and cells due to low molecular weight. Thus they have approximately $100 \%$ bioavailability characteristic and the response relationship based on the applied dose is more significant compared to UH. Not requiring laboratory observation is an advantage, elimination half life is longer and dose-independent contrary to $\mathrm{UH}$. UH presents a heterogeneous structure with its molecular weight, anticoagulant activity and pharmacokinetic characteristics (24). Weak plasma efficiency even in individuals with normal BMI and presentation of unstable pharmacokinetic characteristics causes suspicions on its use in obese patients. Based on a comprehensive literature search comparing $\mathrm{UH}$ and LMWH prophylaxis in bariatric surgery, no superiority was reported in terms of VTE and bleeding complications (23). Two factors caused us to prefer LMWH in our study. These were the indefinite use of $\mathrm{UH}$ in obese patients and LMWH's ease of use for prophylaxis after discharge from hospital.

Although the dose amounts used in heparin treatment are mostly calculated based on weight, the efficiency of these doses in obese patients is controversial (23). Standard dose and weightadjusted dose strategies were compared for optimum prophylactic heparin dose investigation in bariatric surgery patients. In a study including literature search, the authors reported that standard VTE prophylaxis dose was as effective as a weight-adjusted dose with less bleeding complications (25). In a metaanalysis comparing weight-adjusted prophylaxis with lower constant dose prophylaxis, Ikesaka et al (26) reported that lower ( $2 \%$ vs $0.5 \%$ ) and increased major bleeding risk were not observed in the weightadjusted prophylaxis group. In a multi-centered study using two different doses of LMWH for prophylaxis, randomization was provided on 250 patients with parnaparine 4.250 IU/day (standard prophylactic dose) or $6.400 \mathrm{IU} /$ day (150\% of standard dose). The study dose was given for $9 \pm 2$ days pre and postoperatively and no difference in gender, age, BMI, operation duration and other VTE risk factors was reported among the groups. VTE rates were found as $1.5 \%$ and $0.8 \%$ in standard and increased dose groups with no statistically significant difference (27). In another randomized study, Kalfarentzos et al (28) compared daily Nadroparin 5.700 IU SC (standard prophylactic dose) with daily $9.500 \mathrm{IU}$ subcutaneous ( $167 \%$ of standard dose). VTE incident was not observed in both groups but major trauma was detected in two patients in a high dose group compared to a standard dose group. In another study adjusting LMWH dose according to BMI, VTE was not observed but bleeding was reported in five patients (29).

While VTE incidence was between $0-2 \%$ in patients who had standard dose prophylaxis in the studies mentioned above, this rate changed between $0-1 \%$ in increased dose application (26-28). The increased dose provided a little decrease in VTE incidence. On the other hand, increased LMWH dose brings along bleeding possibility $(28,29)$. VTE incidence was 
found $2.2 \%$ in our study and no bleeding complication were present. According to the mentioned studies, partially high VTE incidence and lack of bleeding can be related to standard dose prophylaxis.

VTE incidences may occur at the early postoperative or late term after discharge from hospital. Studies stating that most VTE complications occur after being discharged from the hospital suggest an extended thromboprophylaxis approach (8). The same study reported that the VTE incidence increased to $1.9 \%$ from $0.3 \%$ between postoperative 7 and 30th days. VTE incident was not observed after being discharged from the hospital in our patients. We think that the detailed informing of the patients was effective in this result as patient compliance plays a significant role in VTE incidents after discharge. Not using the drugs prescribed for prophylaxis, inadequate fluid intake and mobilization negatively affect the results. Thus, patients should be informed in detail on VTE risk and the severity of its results after discharge. Raftopoulos et al (30) compared the daily addition of $40 \mathrm{mg}$ enoxaparin for 10 days after being discharged with 30 mg enoxaparin application two times a day until being discharged from hospital. $4.5 \%$ of the group which only received prophylaxis in the hospital experienced VTE incident (three PE and three DVT) and no VTE incident was reported in the second group. In the analysis of prospective studies covering 735 patients who had long term (1-3 weeks) thromboprophylaxis with standard dose LMWH, no postoperative VTE and significant bleeding was reported and LMWH was reported as safe (31). Tseng et al (6) reported $0.5 \%$ postoperative VTE in patients who were administered long term (10 days) prophylaxis with weight adjusted tinzaparin. Prolonged regimen is reported to be effective in preventing VTE complications after bariatric surgery and safe in terms of bleeding (30, 32).

PE developed during hospitalization in two of our patients. There was no surgical procedure or patient related difference in both patients. The observance of PE during hospitalization despite standard dose prophylaxis makes us consider that increased dose application in early period and standard dose application after discharge could be useful. Yet, an approximate decrease of $1 \%$ in VTE risk stands out in studies with increased dose application. On the other hand, observance of bleeding incidences in increased dose application is another challenging condition. Our study had some limitations. The most important limitation was the low number of cases. Especially the low number of complications compared to the number of patients failed to provide a statistical result. As a result, despite available prophylaxis methods, VTE continues to present an important morbidity and mortality cause in patients who had bariatric surgery. While high-dose LMWH use may cause bleeding, the possibility of VTE increases with using low-dose LMWH. This situation appears as a limitation of LMWHs. New studies are needed for an increased dose at an early period and standard dose application after discharge.

\section{Acknowledgment}

We thank Prof. Dr. Faruk Aksoy for his contribution in the surgery of the cases.

Conflict of interest: Authors declare that there is no conflict of interest between the authors of the article.

Financial conflict of interest: Authors declare that they did not receive any financial support in this study.

Address correspondence to: Mehmet Isik, Necmettin Erbakan University, Meram Faculty of Medicine, Department of Cardiovascular Surgery, Konya, Turkey e-mail:drmisik@hotmail.com

\section{REFERENCES}

1. Christakis NA, Fowler $\mathrm{JH}$. The spread of obesity in a large social network over 32 years. N Engl J Med 2007;357(4):3709.

2. Türkiye beslenme ve sağlık araştırması 2010 http://www. sagem.gov.tr/TBSA_Beslenme_Yayini.pdf

3. O'Brien PE, Hindle $\bar{A}$, Brennan $\bar{L}$, et al. Long-term outcomes after bariatric surgery: A systematic review and metaanalysis of weight loss at 10 or more years for all bariatric procedures and a single-centre review of 20-year outcomes after adjustable gastric banding. Obes Surg 2019;29(1):3-14.

4. De Maria EJ. Bariatric surgery for morbid obesity. N Engl J Med 2007;356(21):2176-83.

5. Picot J, Jones J, Colquitt JL, et al. The clinical effectiveness and cost-effectiveness of bariatric (weight loss) surgery for obesity: A systematic review and economic evaluation. Health Technol Assess 2009;13:1-190.

6. Tseng EK, Kolesar E, Handa P, et al. Weight-adjusted tinzaparin for the prevention of venous thromboembolism after bariatric surgery. J Thromb Haemost 2018;16:2008-15.

7. Stein PD, Matta F. Pulmonary embolism and deep venous thrombosis following bariatric surgery. Obes Surg 2013;23(5):663-8.

8. Froehling DA, Daniels PR, Mauck KF, et al. Incidence of venous thromboembolism after bariatric surgery: $A$ population-based cohort study. Obes Surg 2013;23(11):18749.

9. Melinek J, Livingston E, Cortina G, et al. Autopsy findings following gastric bypass surgery for morbid obesity. Arch Pathol Lab Med 2002;126(9):1091-5.

10. Allman-Farinelli MA. Obesity and venous thrombosis: A review. Semin Thromb Hemost 2011;37(8):903-7. 
11. Allman-Farinelli MA, Chey T, Bauman AE, et al. Age, period and birth cohort effects on prevalence of overweight and obesity in Australian adults from 1990 to 2000. Eur J Clin Nutr 2008;62(7)898-907.

12. Erkoçak ÖF, Erkoçak R, Kara İ, et al. Ortopedik cerrahide intraoperatif masif pulmoner emboli. Selçuk Tıp Dergisi 2010;26:150-2.

13. Kellie RB, Jonathan BT. Hypercoagulable stales in venous disease. In: Gloviczki P, Yao JST. Hand book of Venous Disorders. London: Arnold 2001:84-93.

14. Herold CJ, Bankier AA, Burghuber OC, et al. Pulmonary embolism: Pulmonary vascular disorders, vasculitides and hemorrhage. In: Albert RK, Spiro SG, Jett JR (eds). Comprehensive Respiratory Medicine. Philadelphia: Mosby1999;pp:1-12.

15. Finks JF, English WJ, Carlin AM, et al. Predicting risk for venous thromboembolism with bariatric surgery: Results from the Michigan bariatric surgery collaborative. Ann Surg 2012;255(6):1100-4.

16. Masoomi $H$, Buchberg $B$, Reavis $K M$, et al. Factors predictive of venous thromboembolism in bariatric surgery. Am Surg 2011;77(10):1403-6.

17. Steele KE, Schweitzer MA, Prokopowicz G, et al. The longterm risk of venous thromboembolism following bariatric surgery. Obes Surg 2011;21(9):1371-6.

18. Gonzalez R, Haines K, Nelson LG, et al. Predictive factors of thromboembolic events in patients undergoing Roux-en- $Y$ gastric bypass. Surg Obes Relat Dis 2006;2(1):30-5.

19. Chan MM, Hamza N, Ammori BJ. Duration of surgery independently influences risk of venous thromboembolism after laparoscopic bariatric surgery. Surg Obes Relat Dis 2013;9(1):88-93.

20. Jamal $\mathrm{MH}$, Corcelles $\mathrm{R}$, Shimizu $\mathrm{H}$, et al. Thromboembolic events in bariatric surgery: A large multi-institutional referral center experience. Surg Endosc 2015;29(2):376-80.

21. SachdevaA, Dalton $M, A$ maragiri SV, etal. Elastic compression stockings for prevention of deep vein thrombosis. Cochrane Database Syst Rev 2010;(7):CD001484.

22. Urbankova J, Quiroz R, Kucher N, et al. Intermittent pneumatic compression and deep vein thrombosis prevention. A meta-analysis in postoperative patients. Thromb Haemost 2005;94(6):1181-5.
23. Bartlett MA, Mauck KF, Daniels PR. Prevention of venous thromboembolism in patients undergoing bariatric surgery. Vasc Health Risk Manag 2015;11:461-77.

24. Fareed J, Hoppensteadt DA, Bick RL. An update on heparins at the begining of the new millenium. Semin Thromb Hemost 2000;26(suppl 1):5-21.

25. Becattini C, Agnelli G, Manina G, et al. Venous thromboembolism after laparoscopic bariatric surgery for morbid obesity: Clinical burden and prevention. Surg Obes Relat Dis 2012;8:108-15.

26. Ikesaka R, Delluc A, Le Gal G, et al. Efficacyand safety of weight-adjusted heparin prophylaxis for the prevention of acute venous thromboembolism among obese patients undergoing bariatric surgery: A systematic review and metaanalysis. Thromb Res 2014;133:682-7.

27. Imberti D, Baldini E, Pierfranceschi MG, et al. Prophylaxis of venous thromboembolism with low molecular weight heparin in bariatric surgery: A prospective, randomised pilot study evaluating two doses of parnaparin (BAFLUX study). Obes Surg 2014;24(2):284-91.

28. Kalfarentzos F, Stavropoulou F, Yarmenitis S, et al. Prophylaxis of venous thromboembolism using two different doses of low-molecular-weight heparin (nadroparin) in bariatric surgery: A prospective randomized trial. Obes Surg 2001;11(6):670-6.

29. Singh K, Podolsky ER, Um S, et al. Evaluating the safety and efficacy of BMl-based preoperative administration of low-molecular-weight heparin in morbidly obese patients undergoing Roux-en-Y gastric bypass surgery. Obes Surg 2012;22(1):47-51.

30. Raftopoulos I, Martindale C, Cronin A, et al. The effect of extended post-discharge chemical thromboprophylaxis on venous thromboembolism rates after bariatric surgery: A prospective comparison trial. Surg Endosc 2008;22(11):238491.

31. Magee CJ, Barry J, Javed S, et al. Extended thromboprophylaxis reduces incidence of postoperative venous thromboembolism in laparoscopic bariatric surgery. Surg Obes Relat Dis 2010;6:322-5.

32. Almarshad FM, Almegren $\mathrm{M}$, Alshuaibi $\mathrm{T}$, et al. Thromboprophylaxis after bariatric surgery. Blood Res 2020;55(1):44-8. 